\title{
Vale la pena vivir II - Conversaciones en La Conquista'
}

\author{
Más vivencias de Norberto Herrera Zúniga
}

Por Alejandro Serrano Caldera ${ }^{3}$

Vale la pena vivir II, de Norberto Herrera, continúa la relación de nuevas vivencias, cuyos escritos iniciales dieron origen al primer libro con ese nombre sobre algunas de sus experiencias.

Los relatos de Vale la pena vivir II, reflejan las características esenciales no sólo del escritor como tal, sino también de la persona, fundidos en una sola identidad que hace de la narración una expresión de la vida de quien escribe, y de la vida de éste, una experiencia fundamental y un sujeto de la narración construido por los textos del autor.

La lectura del libro en sus diferentes secciones nos revela

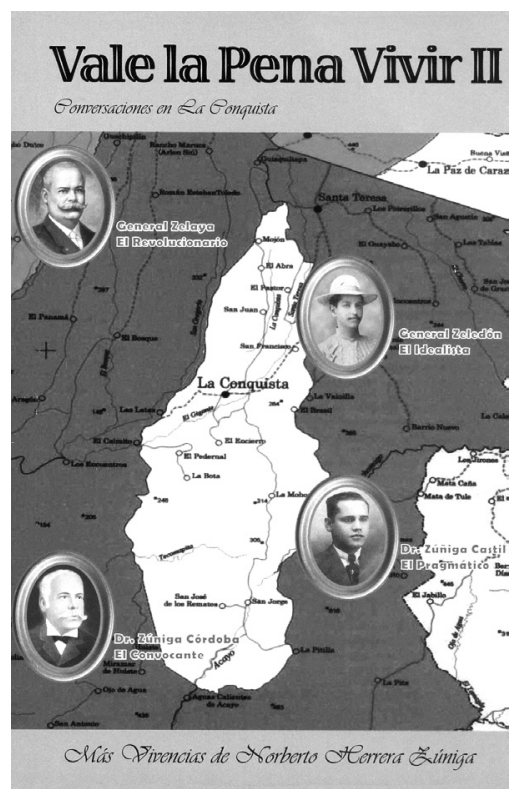

Zúñiga Castillo (Zuca); y el doctor y general Camilo Zúniga Córdoba (Zuco), abuelo del escritor.

Una situación semejante en lo que concierne a la integración racional o sensible del autor, se producirá en la que se refiere a la Universidad Politécnica "La UPOLI: Innovándose para poder seguir 'Sirviendo a la Comunidad'", en donde analiza y reconoce la gestión de la doctora Lidya Ruth Zamora, actual Rectora de la institución.

De igual manera en la sección "Miscelánea vivencial", en la que como el propio Norberto lo expresa, se "trata de relatos cortos, anécdotas $\mathrm{y}$ añoranzas, $\mathrm{y}$ otras inquietudes personales" sobre gentes y eventos; el contexto narrado, pero nos revela también la sensibilidad del escritor y su forma racional o intuitiva, o ambas a la vez, de apreciar los acontecimientos y sus circunstancias.

Cada sección está formada por su propio núcleo temático sin relación contextual o real con los demás, pero todos y cada uno de ellos en sus singularidades y diferencias, contribuyen a poner de manifiesto la sensibilidad emotiva o la racionalidad interpretativa del autor.

Es así que a la vez que nos narra los hechos que forman las diferentes secciones, nos dice o sugiere, expresa o tácitamente, su propia percepción de los acontecimientos descritos cuando se refiere a las "Conversaciones en la Conquista", en las que dialogan el general José Santos Zelaya (Zela); el general Benjamín Zeledón (Zele); el doctor Alejandro o en la sección "Vivencias visuales", que recogen a través de recuerdos fotográficos, imágenes y momentos significativos en la sensibilidad del autor.

Este libro, además de lo que nos cuenta en las diferentes situaciones y momentos que describe, además del relato de los acontecimientos, incide sobre la imaginación y sensibilidad del lector, el que a su vez reconstruye esa circunstancia desde su propia perspectiva, o evoca otras, semejantes o diferentes, que forman parte de la experiencia personal de cada quien.

En esta forma Norberto sin proponérselo, o quizás buscándolo deliberadamente, provoca un diálogo silencioso entre el autor, el lector y la circunstancia narrada, haciendo de la lectura un saludable ejercicio de la imaginación y el recuerdo.

\footnotetext{
1 Managua, Nicaragua, ARDISA, noviembre 2015, $214 \mathrm{pp}$.

2 Rector Fundador de la Universidad Politécnica de Nicaragua (UPOLI):

3 Filósofo y jurista nicaragüense.
} 